\title{
The Application of Case Teaching Method in Western Economics Teaching
}

\author{
Jinlei Yang \\ Zaozhuang College \\ Zaozhuang, China
}

\author{
Zhenqi Wang \\ Bank of China Zaozhuang Branch \\ Zaozhuang, China
}

\begin{abstract}
Western economics consists of two parts: "microscopic" and "macro". This course is a compulsory basic course for economic management major. So, how to improve the teaching of Western economics? This article believes that using the case method to learn the relevant theory of the course is especially important for beginners. Therefore, this article chooses to proceed from the characteristics of the course and in-depth exploration of the use of case teaching methods to improve the teaching quality of Western economics.
\end{abstract}

Keywords-case teaching method; western economics; application

\section{INTRODUCTION}

The so-called Western economics is the product of the western capitalist ideology. It mainly studies the knowledge of the Western market economy and its purpose promotes the best interests of contemporary capitalism. So, how to improve the teaching quality of western economics? This article believes that if we want to learn Western economics well, we must understand and study western economics, especially contemporary western economics.

\section{A. Western Economics Has a Strong Theoretical System}

The microeconomic part is based on the economic behavior of a single economic unit, which mainly addresses resource allocation issues. Among them, the price theory as the central theory, the main use of mathematical analysis to study issues; macroeconomics is the overall operation of the national economy as the research object, mainly to solve the full use of resources. Among them, the income theory as the central theory, the main use of the total analysis method to study the problem. The common characteristics of microeconomics are based on basic concepts, put forward hypotheses, and construct theoretical models to study economic issues. ${ }^{[1]}$

\section{B. Diversification of Research Results in Western Economics}

After the continuous development and improvement of Western economics, its research fields have been continuously extended and research methods have become increasingly rigorous. However, due to the differences in policy proposals of different schools of thought, the dispute between the various factions has never stopped. From the perspective of modern western economics, it includes monetarism, rational anticipation school, supply school, new Keynesianism, New Cambridge school, and new institutional school.

\section{The Combination of Theory and Practical Issues}

As an important theoretical system of the operating mechanism of the market economy of capitalist countries, Western economics can better analyze and explain a wide range of economic phenomena. For example, in addition to the economic issues such as the inflation rate and economic growth, there are basic concepts such as the legal reserve ratio and GDP, all of which can allow people to understand economic issues and also allow people to grasp the direction of economic operation. ${ }^{[2]}$

\section{The Significance of CASE Teaching IN WEStern ECONOMICS}

The so-called case teaching method is based on the students' mastery of basic knowledge and analytical skills. Under the careful planning and guidance of the teacher, according to the teaching purpose and the content of the teaching, the typical case is used to bring the students into the context of the specific event. Case analysis, and through the student's independent thinking and collective collaboration, to improve students' ability to identify, analyze and solve specific problems related to a teaching method. Therefore, using case teaching is of great significance to improving the quality of teaching. ${ }^{[3]}$

\section{A. It Is of Practical Significance to Stimulate Students' Passion for Learning}

In view of the characteristics of Western economics' own curriculum, especially the knowledge system of economics is too abstract, it also involves a large number of concepts, mathematical derivation and economic models. In this regard, through the introduction of case analysis methods, it is possible to construct bridges between relevant economic theories and real economic problems, and it is also possible to link textbook theory knowledge with social hot economic issues better. And through the collection and reflection of student participation in case materials, students can also effectively stimulate their interest in learning economic theory and their enthusiasm for real economic issues. 


\section{B. It Is of Practical Significance to Train Students' Economic Thinking}

Western economics is the study of "receiving the people through the world". Due to the special status of this course, it was determined that teaching activities should not only be limited to basic concepts and related theoretical teaching, but should also introduce relevant historical background to students. At the same time, we must also strengthen the teaching of economic methodology so that it is more conducive to cultivating students' thinking in economics and lay the foundation for the follow-up of specialized courses. Therefore, students' self-study, collaborative discussion, and introduction of teaching cases can lead students to think deeply and explore the interest of the problem.

\section{It Is of Practical Significance to Enhance the Interaction between Teachers and Students}

The general teaching methods are teacher-centered, and the teacher speaks to students. This passive acceptance of knowledge is not conducive to students' understanding and digestion. In the case teaching, teachers carefully selected and designed the case to attract students' attention, guide students to actively initiate thinking and inquiry, and promote students to participate in the learning interaction. Sometimes they can also be supplemented by small experimental cases to transform students into the main position.

According to the traditional teacher's teaching of duckfeeding method of listening to students and ignoring the interaction in the classroom, it is difficult for teachers to understand the level of mastery of students in a timely manner, and it is impossible to reasonably adjust the content of teaching and the progress of teaching. It is only based on the theoretical introduction of this textbook, which is both abstract and boring. The teaching method sets teachers as planners and moderators, students explore and discuss on their own, summarize their own comments, effectively improve the effectiveness of classroom teaching, and make economic theories easy to understand.

\section{SUGGESTIONS FOR CASE TEACHING IN WESTERN ECONOMICS TEACHING}

\section{A. Teachers' Selected Teaching Cases}

The choice of teaching cases is the key to achieving the expected results of teaching. At this time, teachers should play a leading role in selecting and designing cases before class. Most of the classic cases on the textbooks have strong western cultural colors. The way teachers collect cases are generally domestic newspapers and magazines, online hotspots, and television economics. The selection of Western economic cases should focus on the hot issues of China's economic development. With locality and timeliness, practicality can be more prominent.

\section{B. Select Applicable Supplementary Materials}

Qualified teaching and learning materials enable students to comprehensively and systematically grasp the overall content, main conclusions, and application conditions of western economics through the study of Western economics courses. In addition, they can help students remember and understand the main points of teaching content. Therefore, improving course construction by selecting suitable tutorial materials will help realize the transition from traditional mission education to self-directed learning, help students understand the main points in memory teaching content, optimize the teaching content, and optimize teaching content. teaching method.

\section{Adopt Flexible and Flexible Case Analysis}

The form of the case teaching method is rich in content. In the western economics curriculum, different case forms have different statuses and teaching effects. Teachers should select effective case forms for different teaching goals.

One is interspersed case teaching. In teaching the basic concept theory, teachers interspersed with actual cases to deepen students' understanding of the theory and lead students to think. The second is comprehensive case analysis. After the conclusion of several chapters on the theoretical issues taught, teachers can consciously select cross-section comprehensive case, the knowledge points in series to train students to analyze the ability to handle complex cases. The third is special lectures. The university campus regularly invites some experts from inside and outside universities and entrepreneurs to focus on the basic theories of economics and carry out special lectures on current hot economic issues. Teachers can organize the participation of relevant professional students. The fourth is to practice in person. Teachers can combine teaching content with government agencies, enterprises, institutions and research institutions to establish cooperative relations, expand the practice base, and organize student internships. ${ }^{[4]}$

\section{Combining Multiple Teaching Methods to Improve Teaching Quality}

The first is the use of multimedia teaching. In Western economics courses, multimedia teaching can provide a large number of graphical presentations, intuitive display of curve changes in economic models, and quick summary of teaching cases. This is one of the effective means to develop case teaching. The second is to reform the course assessment method. Scientific assessment methods can effectively improve the overall teaching effect, and can also stimulate students' enthusiasm for learning. It is one of the effective ways to carry out quality education and improve teaching quality. Therefore, learning should actively reform the single closed-book assessment in traditional teaching and turn it into a flexible and varied assessment form.

\section{CONCLUSION}

In short, scientific and effective case teaching is conducive to the improvement of students' learning ability and comprehensive quality, which is conducive to the improvement of the quality of college teaching. However, the construction of case teaching methods in Western economics courses is a long-term and continuous 
improvement process. It can never be completed overnight. The optimization of teaching content, the research of teaching methods and methods, the compilation and improvement of teaching materials and related guidance materials, no need for long-term accumulation, can be described as "frozen three feet a day cold." It is also necessary for us to continuously explore and improve the perfect integration of the curriculum.

\section{REFERENCES}

[1] Zeng Lingqiu, Du Wei. Several Issues on Improving the Teaching Quality of "Western Economics"[J]. Journal of Sichuan Normal University, 2002(5):128-131.

[2] Tan Chongtai. How to Treat Western Economics [J]. Contemporary Finance and Economics, 1997(12):3-9.

[3] Chen Xuemei. Western Economics Teaching Should Grasp Several Main Lines[J]. Journal of Jinan University, 2001(6):96-99.

[4] Cai Xiuling,Deng Chunning. Reflections on Several Issues in the Teaching Reform of Western Economics [J]. Fujian Forum (Humanities and Social Sciences Edition), 2007(6):43-46. 